\title{
Catalytically active gold clusters with atomic precision for noninvasive early intervention of neurotrauma
}

\author{
Yunguang Zhang ${ }^{1 \dagger}$, Si Sun ${ }^{2 \dagger}$, Haile Liu${ }^{2}$, Qinjuan Ren ${ }^{2}$, Wenting Hao ${ }^{3}$, Qi Xin ${ }^{3}$, Jiangang $\mathrm{Xu}^{1 *}$, Hao Wang ${ }^{3 *}$ and \\ Xiao-Dong Zhang ${ }^{2,3^{*}}$
}

\begin{abstract}
Background: Neurotrauma is a worldwide public health problem which can be divided into primary and secondary damge. The primary damge is caused by external forces and triggers the overproduction of peroxides and superoxides, leading to long-lasting secondary damage including oxidative stress, wound infection and immunological reactions. The emerging catalysts have shown great potential in the treatment of brain injury and neurogenic inflammation, but are limited to biosafety issues and delivery efficiency.
\end{abstract}

Results: Herein, we proposed the noninvasive delivery route to brain trauma by employing highly active gold clusters with enzyme-like activity to achieve the early intervention. The decomposition rate to $\mathrm{H}_{2} \mathrm{O}_{2}$ of the ultrasmall gold clusters is 10 times that of glassy carbon (GC) electrodes, indicating excellent catalytic activity. The gold clusters can relieve the oxidative stress and decrease the excessive $\mathrm{O}_{2}{ }^{-}$and $\mathrm{H}_{2} \mathrm{O}_{2}$ both in vitro and in vivo. Besides, gold clusters can accelerate the wound healing of brain trauma and alleviate inflammation via inhibiting the activation of astrocytes and microglia through noninvasive adminstration. decrease the peroxide and superoxide of brain tissue.

Conclusions: Present work shows noninvasive treatment is a promising route for early intervention of brain trauma.

Keywords: Gold clusters, Catalytic activity, Traumatic brain injury, Noninvasive administration

\section{Background}

Traumatic brain injury (TBI) has led to globally death and disability with high mobility [1-3] and caused heavily economic burden as a serious public health issue [46]. The primary brain damage can trigger a cascade of molecular and biochemical events, leading to long-lasting secondary damage including oxidative stress, wound

\footnotetext{
*Correspondence: xjgo@xupt.edu.cn; hao_wang@tju.edu.cn; xiaodongzhang@tju.edu.cn

${ }^{+}$Yunguang Zhang and Si Sun contributed equally to this work

${ }^{1}$ School of Science, Xi'an University of Posts and Telecommunications,

Xi'an 710121, China

${ }^{3}$ Tianjin Key Laboratory of Brain Science and Neuroengineering, Academy

of Medical Engineering and Translational Medicine, Tianjin University, Tianjin 300072, China

Full list of author information is available at the end of the article
}

infection and chronic neurodegenerative diseases [1, 79]. Reactive oxygen species (ROS) and reactive nitrogen species (RNS) can oxidatively impair biomacromolecules in vivo and play a crucial role in the pathophysiology of TBI including hydroxyl radical $(\mathrm{OH} \cdot)$, superoxide anion radicals $\left(\mathrm{O}_{2}{ }^{-}\right)$, hydrogen peroxide $\left(\mathrm{H}_{2} \mathrm{O}_{2}\right)$, nitric oxide radicals (NO.) and peroxynitrite $\left(\mathrm{ONOO}^{-}\right)[1,7,8,10$, 11]. Previous studies have confirmed that TBI can be improved via balancing oxidation reduction by elimination of reactive oxygen and nitrogen species (RONS). Thus, antioxidative biocatalysts with catalase-like (CATlike), superoxide dismutase-like (SOD-like), peroxidase (POD-like) and glutathione peroxidase-like (GPx-like) activities and good stability show great potential in the treatment and diagnosis of TBI through catalytically scavenging the RONS [12-20]. original author(s) and the source, provide a link to the Creative Commons licence, and indicate if changes were made. The images or other third party material in this article are included in the article's Creative Commons licence, unless indicated otherwise in a credit line to the material. If material is not included in the article's Creative Commons licence and your intended use is not permitted by statutory regulation or exceeds the permitted use, you will need to obtain permission directly from the copyright holder. To view a copy of this licence, visit http://creativecommons.org/licenses/by/4.0/. The Creative Commons Public Domain Dedication waiver (http://creativeco mmons.org/publicdomain/zero/1.0/) applies to the data made available in this article, unless otherwise stated in a credit line to the data. 
Earlier studies have shed light on the enzyme-like activities of nanozymes. Carbogenic and gold-based nanozymes exhibited exceeding activity against oxidative stress and neuroinflammation [11, 13, 19, 21, 22]. Nanozymes composed of metals, metallic oxide and alloys like $\mathrm{Pt}, \mathrm{Pd}, \mathrm{Cr}, \mathrm{V}$ and Ce possess high enzymatic activities, beneficial for TBI treatment $[12,14,15,18$, 23, 24]. Especially, the ceria nanozymes showed excellent SOD-like and CAT-like catalytic activities on scavenging RONS via redox cycle between $\mathrm{Ce}^{4+}$ and $\mathrm{Ce}^{3+}$ $[12,18,25]$. Compared with traditional nanozymes, the gold clusters show controllable modulation in catalytic activity and selectivity, which can be improved by increasing the atomic utilization efficiency at atomic levels as well as atomic engineering via atom manipulation [26]. Unlike traditional nanozyme, bioactive gold clusters exhibit the high efficient renal clearance and negligible toxicity even at very high injected dose $(500 \mathrm{mg} / \mathrm{kg})[24,25,27]$. Moreover, due to ultrasmall size, the gold clusters can enter cell or injury site easily, resulting in high efficient treatment $[26,28]$. Gold clusters possess activities like SOD, CAT and GPx enzymes, performing significant antioxidant effects in TBI treatment [26, 28-31]. Though nanotechnologies for TBI diagnosis and monitoring were employed to promote the activity and utilization of nanozymatic biocatalysts like atom engineering, surface modification, and size modulation [32-34], it remains painless and chanllenged for clinical translation [12, 15, 29-31, 35-45]. Different from the intravenous injection, the noninvasive diagnosis and stimulation for TBI can achieve rapid and painless treatment, worthy of considering to promote recovery and minimize disability. However, the noninvasive methods for TBI treatment are still highly challenged.

Herein, we investigated a noninvasive administration to treat brain trauma at the early stage with gold clusters of well-defined structure and high catalytic selectively. Electrochemical assay unraveled their high catalytic activities toward hydrogen evolution reaction (HER) and oxygen evolution reaction (OER), and further revealed their excellent activity toward the reduction of $\mathrm{O}_{2}$ and $\mathrm{H}_{2} \mathrm{O}_{2}$. Furthermore, noninvasive administration of the gold clusters distinctly improved the wound healing on TBI mice and Morris water maze tests further confirmed significant recovery on learning ability and spatial memory with $\mathrm{Au}_{24} \mathrm{Cu}_{1}$ and $\mathrm{Au}_{24} \mathrm{Cd}_{1}$ treatment. Ex vivo assay further proved the ability of gold clusters on mitigating oxidative stress and inhibiting neuroinflammation. Together with the results of acceptable biocompatibility, gold clusters showed promising potential as noninvasive therapeutics against TBI.

\section{Results and discussion}

The $\mathrm{Au}_{25}$ cluster is composed of 13 gold atoms as the core and $6 \mathrm{Au}_{2}(\mathrm{SG})_{3}$ as the outer shell. The catalytically active sites of the cluster are mainly located on the surface. Single atom $\mathrm{Cu}$ or $\mathrm{Cd}$ replaces the $\mathrm{Au}$ in one of the $\mathrm{S}$-Au-S, indicative of synthesizing $\mathrm{Au}_{24} \mathrm{Cu}_{1}$ and $\mathrm{Au}_{24} \mathrm{Cd}_{1}$, respectively. After single atom $\mathrm{Cu}$ and $\mathrm{Cd}$ substitution, the valence electron structure of the cluster is altered, thereby changing the catalytic performance of the cluster [23]. Figure 1a illustrated the effects of MPA-protected $\mathrm{Au}_{25}, \mathrm{Au}_{24} \mathrm{Cu}_{1}$ and $\mathrm{Au}_{24} \mathrm{Cd}_{1}$ clusters in brain trauma via catalytic systems. TEM images illustrated the homogenous distribution of the clusters at about $2 \mathrm{~nm}$ (Fig. 1b, c), similar with L-NIBC-coated gold clusters [46]. The hydrodynamic sizes determined by dynamic light scattering (DLS) were 1.98, 1.92 and $2.58 \mathrm{~nm}$ for $\mathrm{Au}_{25}, \mathrm{Au}_{24} \mathrm{Cd}_{1}$ and $\mathrm{Au}_{24} \mathrm{Cu}_{1}$, respectively, a little larger than the statistical diameter of TEM. After incubation in water for 24 and $48 \mathrm{~h}$, the size of clusters changed negligibly, revealing the favorable stability (Fig. 1d, e). In addition, the zeta potentials of all clusters were around $-35 \mathrm{mV}$ (Fig. 1f), consistent with our previous work [26, 47]. The concentration $\mathrm{Cd}$ and $\mathrm{Cu}$ elements in $\mathrm{Au}_{24} \mathrm{Cd}_{1}$ and $\mathrm{Au}_{24} \mathrm{Cu}_{1}$ clusters account for $3 \%$ and $5 \%$ of the total metal as determined by an accurate inductively coupled plasma mass spectrometry (ICP-MS), respectively, further confirming the single-atom substitution in $\mathrm{Au}_{25}$ clusters (Additional file 1: Fig. S1). X-ray photoelectron spectroscopy (XPS) confirmed that the dominant state of $\mathrm{Au}$ in the clusters is the $\mathrm{Au}(0)$ state, and the peaks of $\mathrm{Cu} 2 \mathrm{p}_{3 / 2}(931.8 \mathrm{eV})$ and $\mathrm{Cd} 3 \mathrm{~d}_{5 / 2}(404.8 \mathrm{eV})$ are on the reducing side of $\mathrm{Cu}(0)$ (id. $=932.2 \mathrm{eV}$ ) and $\mathrm{Cd}(0)($ id. $=405.3 \mathrm{eV}$ ), respectively, indicating the successful single-atom substitution in $\mathrm{Au}_{25}$ clusters (Additional file 1: Fig. S2). These results display the ultrasmall size and good colloid stability of clusters, manifesting the potential in biological applications.

To evaluate the electrocatalytic activities of the $\mathrm{Au}_{25}$, $\mathrm{Au}_{24} \mathrm{Cu}_{1}$ and $\mathrm{Au}_{24} \mathrm{Cd}_{1}$ clusters, a standard three-electrode system were employed to conduct the electrocatalytic activities toward HER and OER [48-50]. Figure 2a shows cyclic voltammetry $(\mathrm{CV})$ curves of glassy carbon (GC) electrodes modified with as prepared $\mathrm{Au}_{25}, \mathrm{Au}_{24} \mathrm{Cu}_{1}$ and $\mathrm{Au}_{24} \mathrm{Cd}_{1}$ clusters. Compared with a blank GC electrode, clusters achieve larger negative current density toward HER (Fig. 2a), which were further verified by linear sweep voltammetry (LSV) measurement (Fig. 2b). As shown in Fig. $2 \mathrm{c}, \mathrm{Au}_{24} \mathrm{Cu}_{1}$ clusters demonstrated a higher efficiency at the potential of $-0.4585 \mathrm{~V}$ in catalysis, significantly better than $\mathrm{Au}_{25}\left(\mathrm{SC}_{12} \mathrm{H}_{25}\right)_{18}$ [8] and PtCo cluster [10]. OER exhibits similar results with HER that all clusters improved the performance of the electrochemical reaction (Fig. $2 \mathrm{~d}, \mathrm{f}$ ). $\mathrm{Au}_{24} \mathrm{Cd}_{1}$ shows the lowest current onset on $\mathrm{CV}$ curves at $1.3 \mathrm{~V}$, followed by $\mathrm{Au}_{24} \mathrm{Cu}_{1}$ 

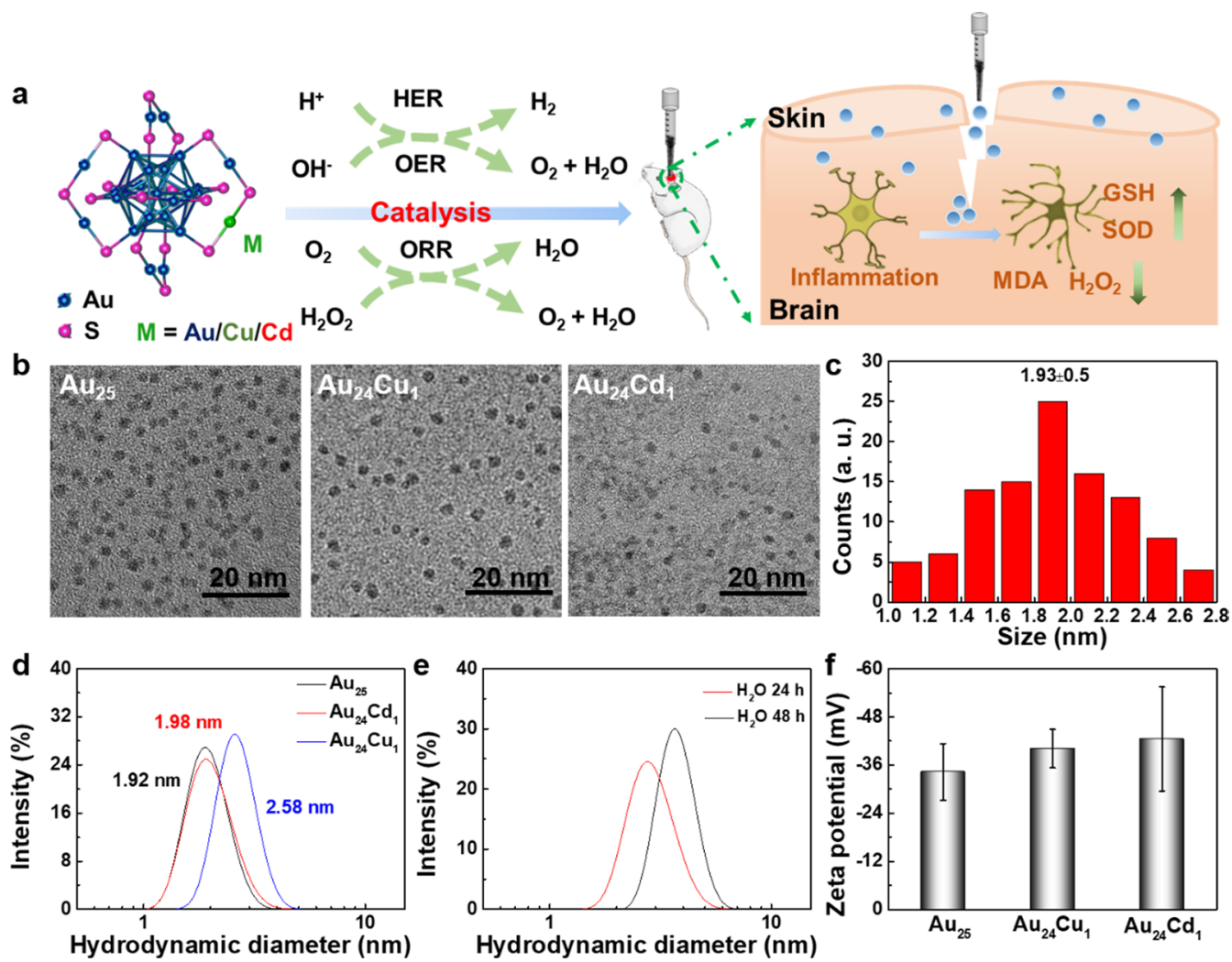

Fig. 1 Structural characterization of $\mathrm{Au}_{25}$ clusters. a Schematic illustration of noninvasive TBI treatment with gold clusters via a catalytic system. $\mathbf{b}$ TEM image of MPA-protected $\mathrm{Au}_{25}, \mathrm{Au}_{24} \mathrm{Cu}_{1}$ and $\mathrm{Au}_{24} \mathrm{Cd}_{1}$ clusters. Scale bar: $20 \mathrm{~nm}$. c Size distribution of MPA-protected $\mathrm{Au}_{25}$ nanocluster measured by analyzing 100 nanodots from TEM images. $\mathbf{d}$ Hydrodynamic diameters of MPA-protected $\mathrm{Au}_{25}, \mathrm{Au}_{24} \mathrm{Cu}_{1}$ and $\mathrm{Au}_{24} \mathrm{Cd}_{1}$ in PBS buffer, and the mean sizes of $\mathrm{Au}_{25}, \mathrm{Au}_{24} \mathrm{Cu}_{1}$ and $\mathrm{Au}_{24} \mathrm{Cd}_{1}$ were 1.98, 1.92 and $2.58 \mathrm{~nm}$ respectively. e Stability of $\mathrm{Au}_{25}$ nanocluster in $\mathrm{H}_{2} \mathrm{O}$ after 24 and $48 \mathrm{~h}$ at room temperature, and the slightly increase of hydrodynamic diameter revealed satisfying stability. Additionally, the zeta potentials of the clusters $\mathbf{f}$ were around $-35 \mathrm{mV}$, indicative of good colloid stability ( $\mathrm{n}=3$ independent experiments, data are presented as mean \pm SD)

and $\mathrm{Au}_{25}$, which is a little different from the results of HER. Besides, $\mathrm{Au}_{24} \mathrm{Cd}_{1}$ can reach $0.023 \mathrm{~mA} / \mathrm{cm}^{2}$ at a potential of $1.3254 \mathrm{~V}$, while that of NiFe clusters is less than $0.01 \mathrm{~mA} / \mathrm{cm}^{2}$, indicating better superiority to $\mathrm{NiFe}$ cluster [11]. The results of HER and OER further demonstrated that the catalytic performance were altered by the valence electron structure change via different singleatom substitution [23].

We also evaluated the in vitro catalytic activities of $\mathrm{Au}_{25}, \mathrm{Au}_{24} \mathrm{Cu}_{1}$ and $\mathrm{Au}_{24} \mathrm{Cd}_{1}$ clusters in $\mathrm{H}_{2} \mathrm{O}_{2}$ reduction and oxygen reduction reaction (ORR) [51, 52]. As shown in Fig. 3a, the current density of the GC electrode modified by $\mathrm{Au}_{24} \mathrm{Cu}_{1}$ clusters can reach $-1.48 \mathrm{~mA} / \mathrm{cm}^{-2}$ at a potential of $-0.8 \mathrm{~V}$, a little higher than $\mathrm{Pt}_{12}$ clusters [18]. The results were further verified by LSV measurement (Fig. 3b), demonstrating that all clusters can enhance the electrocatalytic activity and $\mathrm{Au}_{24} \mathrm{Cu}_{1}$ clusters exhibit the best activity for ORR among all clusters. For the reduction of $\mathrm{H}_{2} \mathrm{O}_{2}$, only imperceptible reduction current was observed in the presence of $\mathrm{H}_{2} \mathrm{O}_{2}$ on the GC electrode, consistent with previous works [51]. Compared with the GC electrode at $-0.8 \mathrm{~V}, \mathrm{Au}_{24} \mathrm{Cu}_{1}$ clusters show the current destiny of $-1.74 \mathrm{~mA} / \mathrm{cm}^{-2}$, and $\mathrm{Au}_{24} \mathrm{Cd}_{1}$ clusters exhibit that of $-1.56 \mathrm{~mA} / \mathrm{cm}^{-2}$ (Fig. 3d, e), slightly better than noble metal (Ag, Pd, Au, Pt) on Graphene/ZnO multihybrid nanoarchitectures [19]. Figure 3c, f quantitatively demonstrate the improvement of all clusters on $\mathrm{O}_{2}$ and $\mathrm{H}_{2} \mathrm{O}_{2}$ reduction, indicating excellent catalytic activities. $\mathrm{Au}_{24} \mathrm{Cu}_{1}$ presented the predominance toward both reactions, and $\mathrm{Au}_{24} \mathrm{Cd}_{1}$ and $\mathrm{Au}_{25}$ followed toward $\mathrm{H}_{2} \mathrm{O}_{2}$ and $\mathrm{O}_{2}$ reduction, respectively.

Since the remarkable catalytic activities inspired us to investigate their biological responses in cells and braininjured mice, we conducted biological inspections to evaluate their activities in vitro and in vivo. Combined with our previous work [26], $\mathrm{Au}_{24} \mathrm{Cd}_{1}$ and $\mathrm{Au}_{24} \mathrm{Cu}_{1}$ clusters conferred catalytic selectivity and enzyme-like activities, beneficial to reduce the oxidative stress induced by brain injury (Fig. 4a). $\mathrm{Au}_{25}, \mathrm{Au}_{24} \mathrm{Cu}_{1}$ and $\mathrm{Au}_{24} \mathrm{Cd}_{1}$ exihibit good biocompatibility at the concentration of $50 \mu \mathrm{g} /$ 

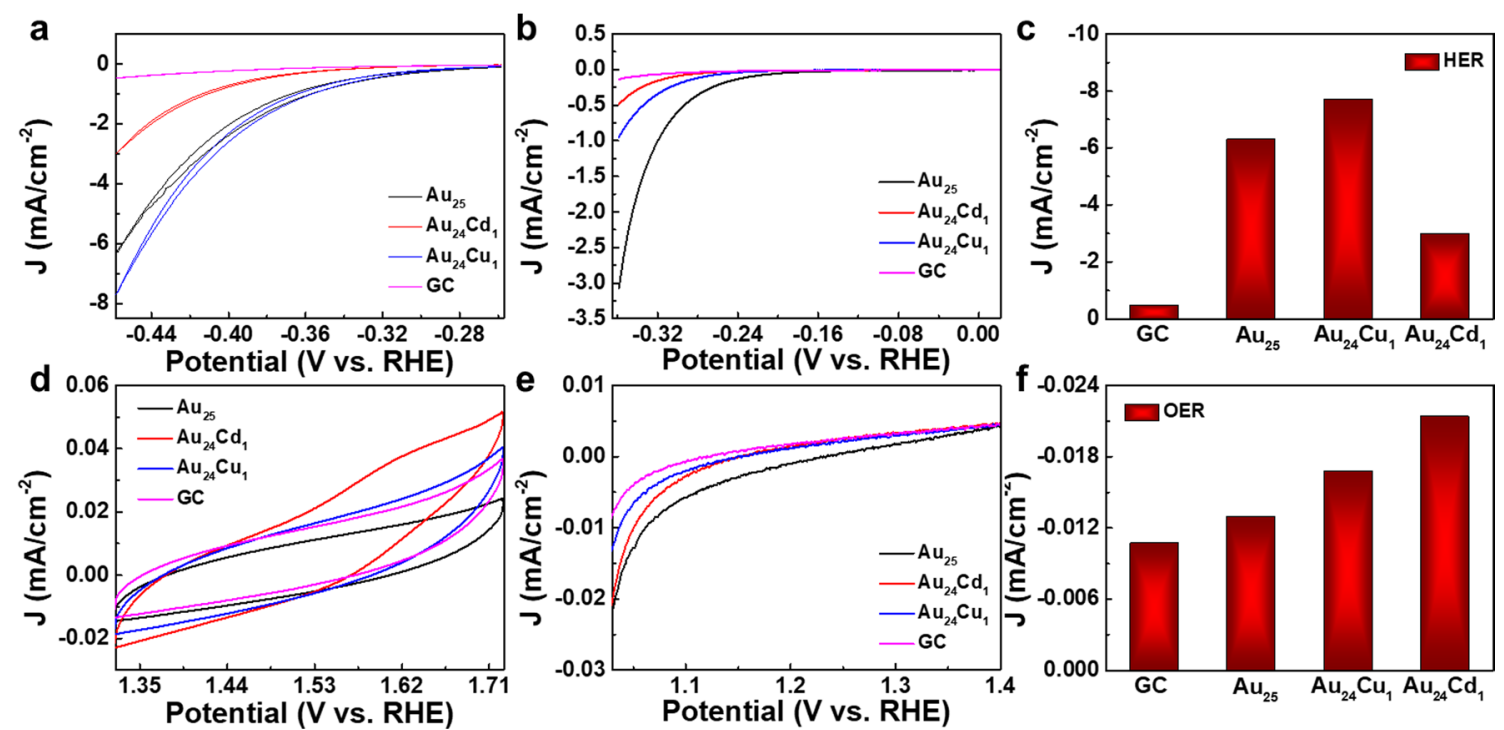

Fig. 2 Catalytic performance for overall water splitting. a CVs of GC electrode modified with as-prepared $\mathrm{Au}_{25}, \mathrm{Au}_{24} \mathrm{Cu}_{1}$ and $\mathrm{Au}_{24} \mathrm{Cd}_{1}$ clusters in $0.5 \mathrm{M} \mathrm{H}_{2} \mathrm{SO}_{4}$. Scanning rate: $0.010 \mathrm{~V} \mathrm{~s}^{-1}$. b Linear sweep HER voltammograms for $\mathrm{Au}_{25}, \mathrm{Au}_{24} \mathrm{Cu}_{1}$ and $\mathrm{Au}_{24} \mathrm{Cd}_{1}$ clusters. Scanning rate: $0.001 \mathrm{~V} \mathrm{~s}^{-1}$. $\mathbf{c}$ Current density of different clusters at the potential of $-0.4585 \mathrm{~V}$ toward the activity of HER. $\mathbf{d}$ CVs of GC electrode modified with as-prepared $\mathrm{Au}_{25}$, $\mathrm{Au}_{24} \mathrm{Cu}_{1}$ and $\mathrm{Au}_{24} \mathrm{Cd}_{1}$ clusters in $1 \mathrm{M} \mathrm{KOH}$. Scanning rate: $0.10 \mathrm{~V} \mathrm{~s}^{-1}$. e Linear sweep OER voltammograms for $\mathrm{Au}_{25}, \mathrm{Au}_{24} \mathrm{Cu}_{1}$ and $\mathrm{Au}_{24} \mathrm{Cd}_{1} \mathrm{Clusters}$ Scanning rate: $0.005 \mathrm{~V} \mathrm{~s}^{-1}$. $\mathbf{f}$ Current density of different clusters at the potential of $1.3244 \mathrm{~V}$ toward the activity of OER
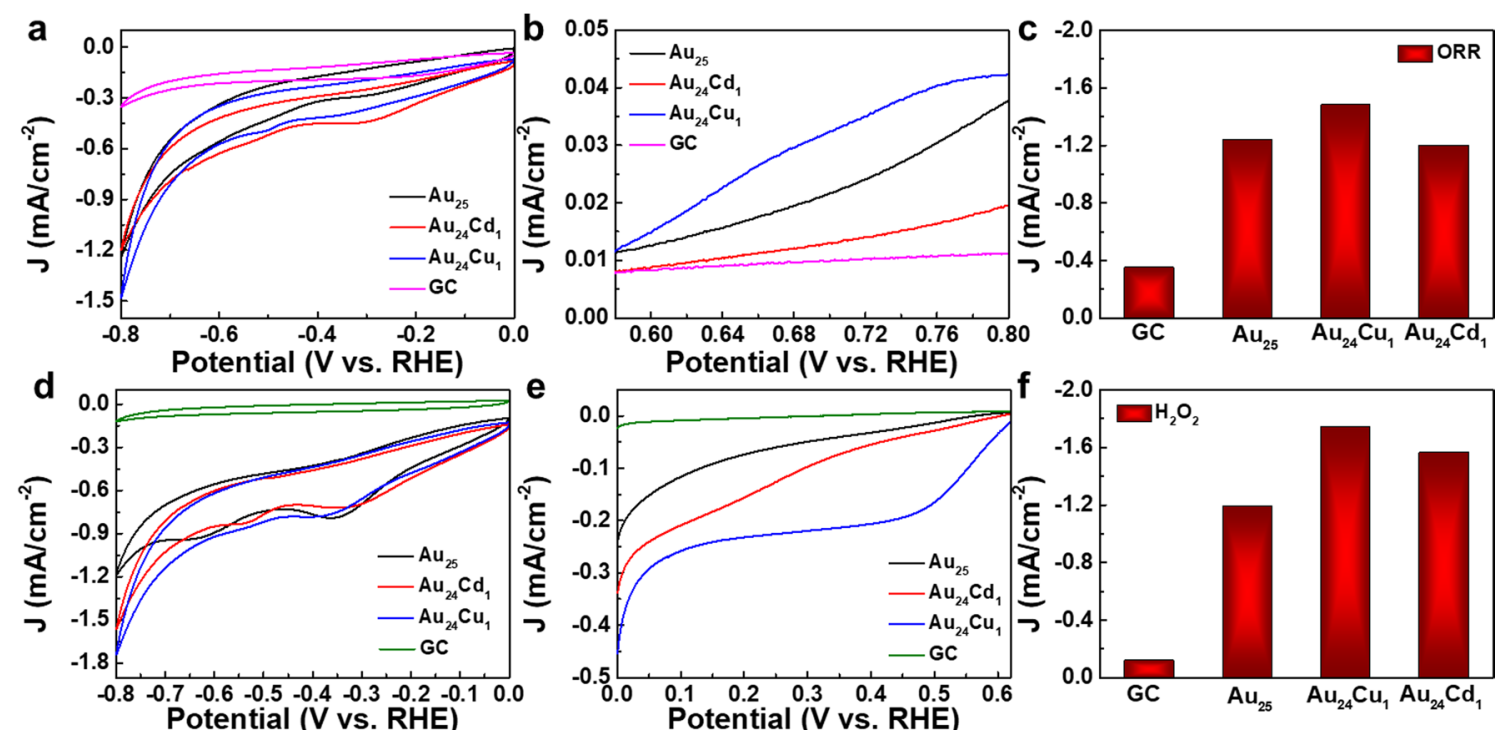

Fig. 3 Catalytic activities of the $\mathrm{Au}_{25}$ clusters. a CVs of GC electrode modified with as-prepared $\mathrm{Au}_{25}, \mathrm{Au}_{24} \mathrm{Cu}_{1}$ and $\mathrm{Au}_{24} \mathrm{Cd}_{1}$ clusters in $\mathrm{O}_{2}$-saturated $0.01 \mathrm{M}$ PBS (pH 7.4). Scanning rate: $0.050 \mathrm{~V} \mathrm{~s}^{-1}$. b LSV of GC electrode modified with as-prepared $\mathrm{Au}_{25}, \mathrm{Au}_{24} \mathrm{Cu}_{1}$ and $\mathrm{Au}_{24} \mathrm{Cd}_{1}$ clusters in $\mathrm{O}_{2}$-saturated $0.01 \mathrm{M}$ PBS (pH 7.4). Scanning rate: $0.005 \mathrm{~V} \mathrm{~s}^{-1}$. c Compared the ORR activities of $\mathrm{Au}_{25}, \mathrm{Au}_{24} \mathrm{Cu}_{1}$ and $\mathrm{Au}_{24} \mathrm{Cd}_{1}$ clusters at the potential of $-0.8 \mathrm{~V}$. $\mathbf{d} \mathrm{CV}$ s of $\mathrm{GC}$ electrode modified with as-prepared $\mathrm{Au}_{25}, \mathrm{Au}_{24} \mathrm{Cu}_{1}$ and $\mathrm{Au}_{24} \mathrm{Cd}_{1}$ clusters in the presence of $9.8 \mathrm{mM} \mathrm{H}_{2} \mathrm{O}_{2}$ in N $\mathrm{N}_{2}$-saturated $0.01 \mathrm{M} \mathrm{PBS}$ ( $\mathrm{pH} 7.4$ ). Scanning rate: $0.050 \mathrm{~V} \mathrm{~s}^{-1}$. e LSV of GC electrode modified with as-prepared $\mathrm{Au}_{25}, \mathrm{Au}_{24} \mathrm{Cu}_{1}$ and $\mathrm{Au}_{24} \mathrm{Cd}_{1}$ clusters in the presence of $9.8 \mathrm{mM} \mathrm{H} \mathrm{O}_{2}$ in $\mathrm{N}_{2}$-saturated $0.01 \mathrm{M} \mathrm{PBS}\left(\mathrm{pH}\right.$ 7.4). Scanning rate: $0.010 \mathrm{~V} \mathrm{~s}^{-1}$. Rotation rate: $1600 \mathrm{rpm}$. $\mathbf{f}$ Compared the $\mathrm{H}_{2} \mathrm{O}_{2}$ scavenging activities of clusters at the potential of $-0.8 \mathrm{~V}$ 

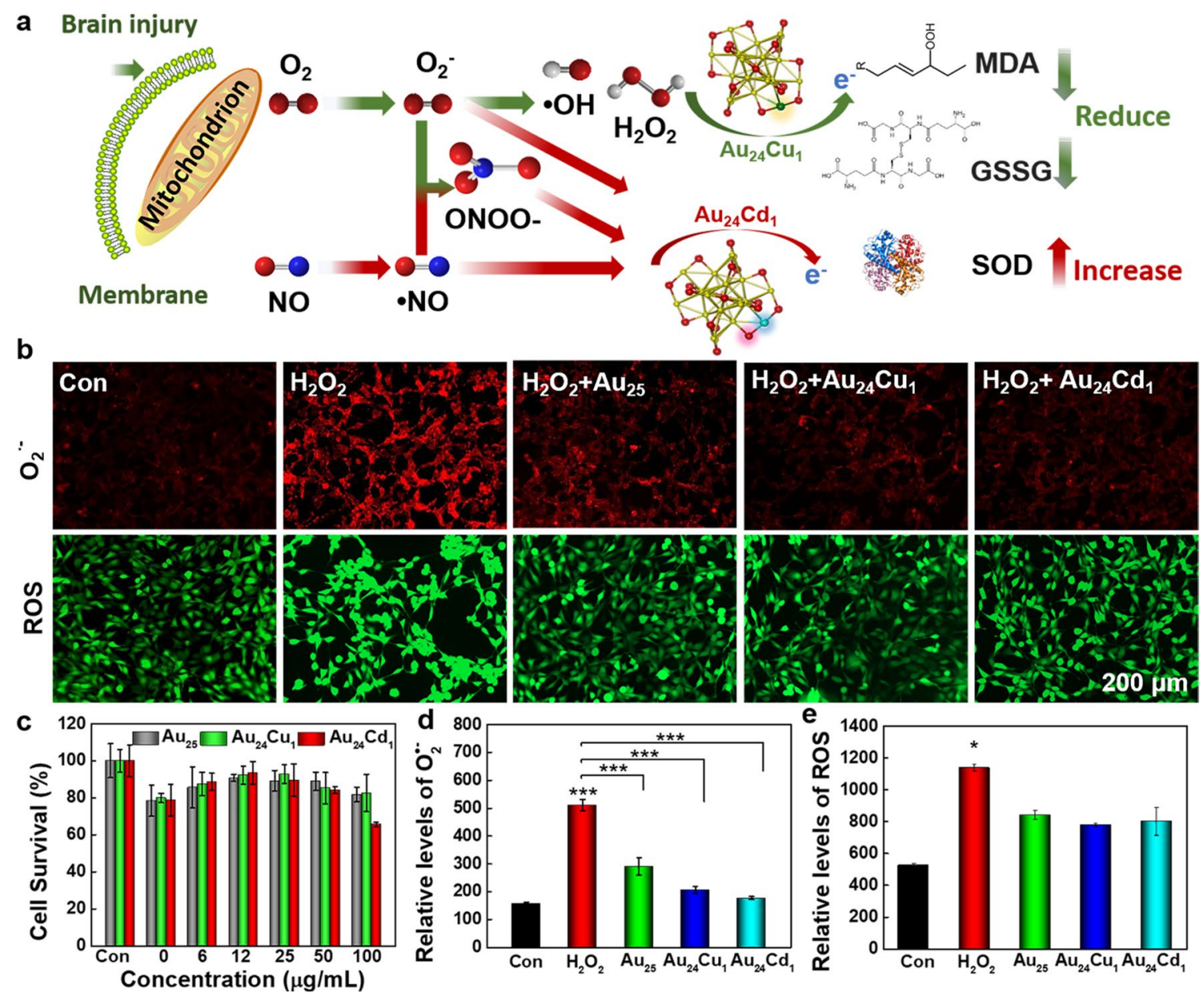

Fig. 4 Catalytic mechanism and in vitro evaluation of the clusters. a Schematic illustration of the catalytic mechanism and selectivity of the clusters. Cu and Cd as single active sites exhibit superiorities against reactive oxygen species (ROS) and reactive nitrogen species (RNS) respectively, resulting in free radical scavenging and inspire their use in brain injury. b Fluorescence images of $\mathrm{ROS}^{(\mathrm{green})}$ and $\mathrm{O}_{2}{ }^{--}$(red) levels induced by 100 $\mu \mathrm{M} \mathrm{H}_{2} \mathrm{O}_{2}$ with or without clusters treatment, illustrating the high activity of scavenging ROS of the clusters. $\mathbf{c}$ HT22 cell viability under treatment of $\mathrm{H}_{2} \mathrm{O}_{2}$ and treated with or without the clusters ( $n=5$ per group, data are presented as mean \pm SD), which showed the ability of the clusters to rescue the lethality induce by $\mathrm{H}_{2} \mathrm{O}_{2}$. $\mathbf{d}$, e Quantitative analysis of $\mathrm{Au}_{25}, \mathrm{Au}_{24} \mathrm{Cu}_{1}$ and $\mathrm{Au}_{24} \mathrm{Cd}_{1}$ against $\mathrm{O}_{2}{ }^{\cdot-}$ and $\mathrm{ROS}$, respectively ( $\mathrm{n}=3$ independent experiments, data are presented as mean $\pm \mathrm{SD}$ ). Data are analyzed by one-way ANOVA with Tukey test (adjusted $p$ values are shown, ${ }^{*} p<0.05$, ${ }^{* * *} p<0.001$, compared with the Con group)

mL to different neural cell lines (HT22, BV2 and MA-c) determined by 3-[4,5-dimethylthiazol-2-yl]-2,5 diphenyltetrazolium bromide (MTT) assays (Additional file 1: Fig. S3), presenting favorable metabolic properties [26].

To investigate the biological activity of clusters, imaging of $\mathrm{H}_{2} \mathrm{O}_{2}$-treated neuron cells with or without $\mathrm{Au}_{25}$, $\mathrm{Au}_{24} \mathrm{Cd}_{1}$ and $\mathrm{Au}_{24} \mathrm{Cu}_{1}$ clusters was obtained (Fig. $4 \mathrm{~b}$ ). The $\mathrm{H}_{2} \mathrm{O}_{2}$ stimulation can significantly elevates signals, indicating the presence of excessive amount of ROS and $\mathrm{O}_{2}^{--}$[53]. All clusters can decrease the ROS and $\mathrm{O}_{2}{ }^{--}$signals, while $\mathrm{Au}_{24} \mathrm{Cd}_{1}$ shows the best clearance efficiency. Meanwhile, $\mathrm{Au}_{24} \mathrm{Cu}_{1}$ displays better clearance capability against $\mathrm{ROS}$ than $\mathrm{Au}_{25}$ and $\mathrm{Au}_{24} \mathrm{Cd}_{1}$, suggesting higher selectivity for ROS. The related quantification further confirmed the remarkable biological catalytic activity and laying the groundwork for in vivo utilization (Fig. 4d, e). In addition, $\mathrm{H}_{2} \mathrm{O}_{2}$ induces decreases in cell viability $(\sim 78 \%)$ due to oxidative stress and inflammation [54], while $\mathrm{Au}_{25}, \mathrm{Au}_{24} \mathrm{Cd}_{1}$ and $\mathrm{Au}_{24} \mathrm{Cu}_{1}$ clusters can rescue cell viability back to $90 \%$, indicative of great potential to protect nerves and lower the lethality from $\mathrm{H}_{2} \mathrm{O}_{2}$-induced cytotoxicity (Fig. 4c). All the in vitro results manifest good catalytic activities of $\mathrm{Au}_{24} \mathrm{Cd}_{1}$ and $\mathrm{Au}_{24} \mathrm{Cu}_{1}$ clusters on ROS scavenging, revealing their potential as biocatalysts and suggesting further investigation in vivo. 
The primary injuries triggers a casade of biochemical reactions, leading to the long-lasting sencondary injuries. The secondary brain injuries generate harmful molecules and cytokines, leading to acute or chronic neuronal damage, memory impairment and inflammation. Traditional intravenous administration have shown great poteintial in brain diseases, but toxicity remains a major concern for clinical translation [15, 28]. Therefore, the above in vitro preliminary results inspired us to treat TBI noninvasively and it is reasonable to develop a noninvasive routine to treat TBI at the early stage. The clusters were dropped in the injured area of TBI mice. The wound size was significantly reduced to healthy levels after clusters treatment, whereas the untreated mice only showed a partial recovery (Fig. 5a, b). We further evaluated the oxidative stress-related indicators, including SOD, GSH/ GSSG, MDA, and $\mathrm{H}_{2} \mathrm{O}_{2}$ in TBI mice $[28,55]$. Brain injuries generate excessive ROS in tissues, consume lots of SOD and GSH, and produce harmful lipid peroxidation (Fig. 5c-f). SOD and GSH/GSSG are sharply decreased

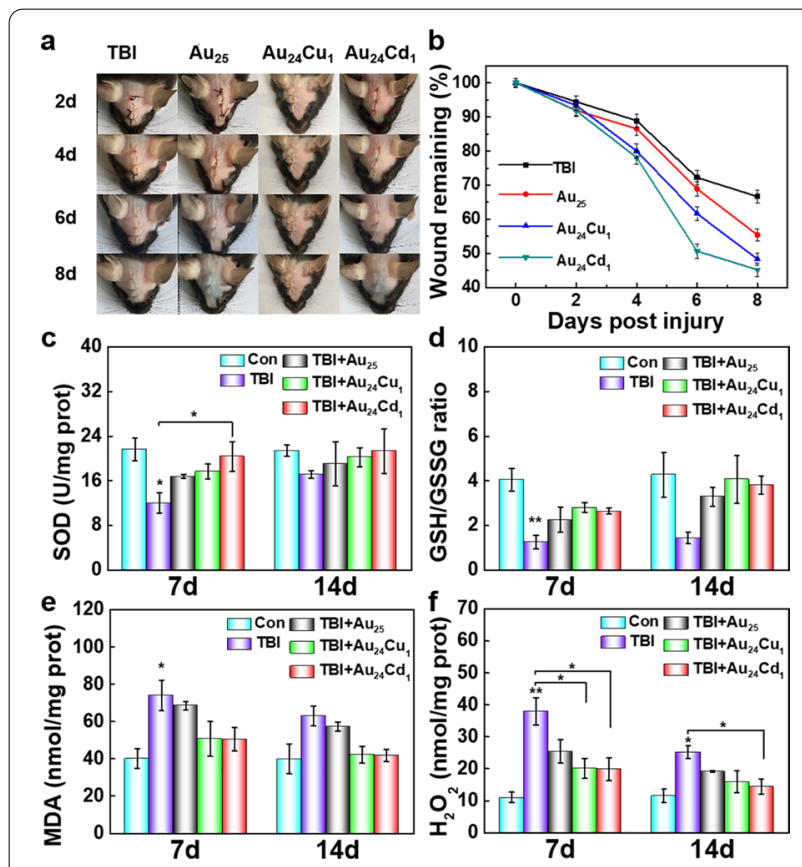

Fig. 5 In vivo investigation of the clusters. a Wound healing processes over time of TBI mice with and without treatment of clusters, and $\mathbf{b}$ showed wound remaining percentage over time. The $\mathrm{Au}_{24} \mathrm{Cu}_{1}$ and $\mathrm{Au}_{24} \mathrm{Cd}_{1}$ showed favorable therapeutic effect against TBI. c-f Indicators for oxidative stress, including SOD, GSH/GSSG, MDA, and $\mathrm{H}_{2} \mathrm{O}_{2}$, of TBI mice with or without treatment of clusters on days 7 and 14 post intervention ( $n=3$ per group). The clusters can rescue the level of SOD and GSH/GSSG decreased by TBI, and decrease the MDA and $\mathrm{H}_{2} \mathrm{O}_{2}$, indicative of alleviating the oxidative stress in vivo. Data are presented as mean \pm SEM and compared with the Con groups, analyzed by one-way ANOVA with Tukey test (adjusted $p$ values are shown, ${ }^{*} p<0.05,{ }^{* *} p<0.005$ ) on day 7 post-injury and slightly increased on day 14 post-injury, and MDA and $\mathrm{H}_{2} \mathrm{O}_{2}$ are relatively serious on day 7 post-injury and a little alleviated on day 14 postinjury for TBI groups, indicating severe oxidative stress after brain injuries. However, clusters can effectively decrease the MDA and $\mathrm{H}_{2} \mathrm{O}_{2}$ levels, suggesting the ROS elimination of clusters, and can siginificantly recovered the SOD and GSH/GSSG levels, maintaining the balance of ROS levels.

Moreover, the behavior tests were conducted to evaluate the spatial learning and memory abilities by Morris water maze (Fig. 6). All mice were trained to learn to search for the platform during the acquisition phase on days 13-17 and 26-30 including the total distance travelled and the latency to the hidden platform. Compared with TBI groups, both travel distance and latency to platform gradually decrease with training after clusters treatment (Fig. 6c, d), indicating that clusters can effectively improve the motor function following brain injury. $\mathrm{Au}_{24} \mathrm{Cu}_{1}$ or $\mathrm{Au}_{24} \mathrm{Cd}_{1}$ clusters show better results than $\mathrm{Au}_{25}$, indicating the efficiency enhancement by $\mathrm{Cu}$ and

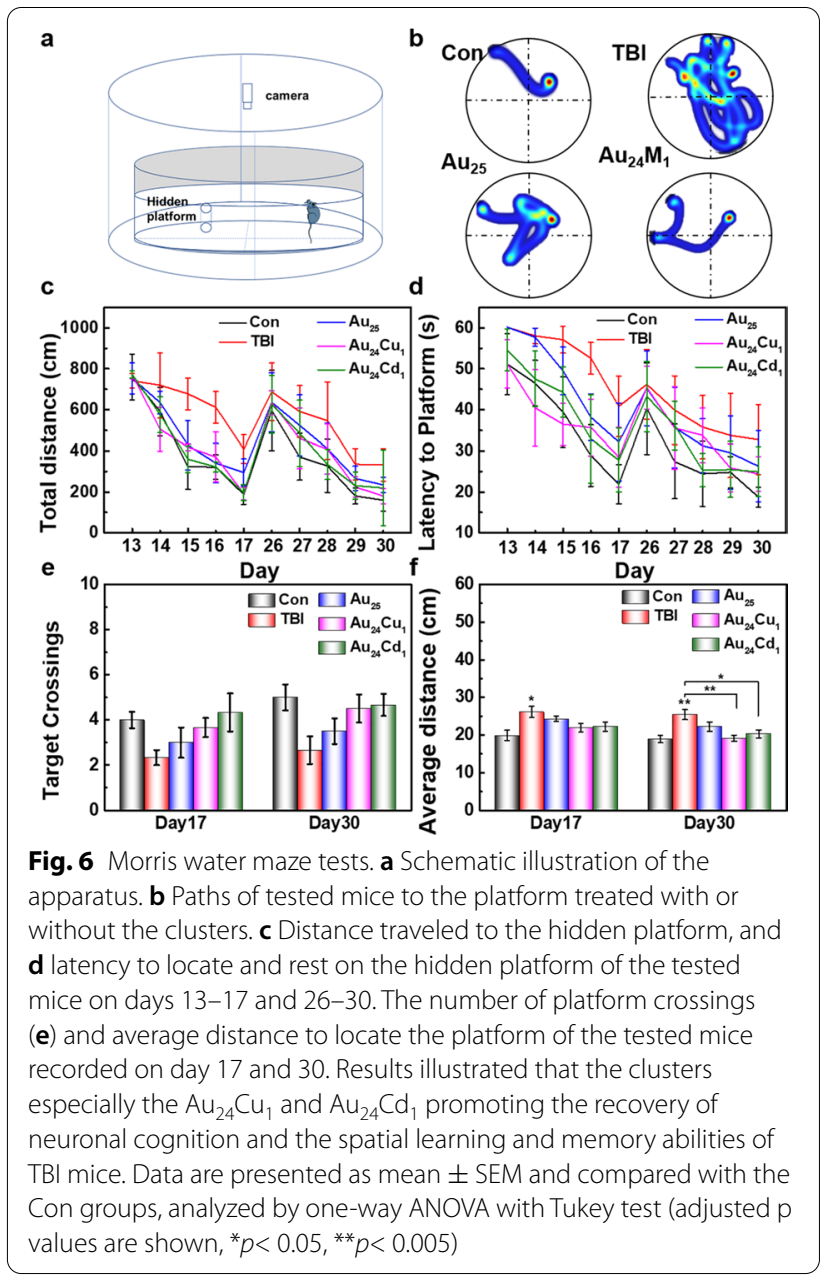


$\mathrm{Cd}$ single-atom substitution. Figure $6 \mathrm{e}, \mathrm{f}$ show that platform crossings and average distance obviously decrease in TBI group and can almost return back to normal levels with cluters treatment after injury. These facts imply that clusters can effectively improve the learning ability and spatial memory of mice with TBI-induced brain injury.

Since brain injuries can lead to chronic inflammation, we were examined their therapeutic effects on the neuroinflammation. Figure $7 \mathrm{a}$ demonstrates the schematic illustration for the TBI-associated inflammatory responses and relevant modulation with the clusters $[1$, 8]. IL-1 $\beta$, IL- 6 and TNF- $\alpha$ are all upregulated after injury, revealing strong local inflammation. $\mathrm{Au}_{25}$ only shows minor downregulation toward the three inflammatory factors, while $\mathrm{Au}_{24} \mathrm{Cd}_{1}$ and $\mathrm{Au}_{24} \mathrm{Cu}_{1}$ exhibit exceptional efficiency to reduce their levels, manifesting that substitution of $\mathrm{Cu}$ and $\mathrm{Cd}$ atom has great influence on the catalytic activity (Fig. 7 b, c). $\mathrm{Au}_{24} \mathrm{Cu}_{1}$ performs better than $\mathrm{Au}_{24} \mathrm{Cd}_{1}$ in downregulating overexpressed TNF- $\alpha$, whereas $\mathrm{Au}_{24} \mathrm{Cd}_{1}$ behaves better in mediating IL-1 $\beta, \mathrm{IL}-6$, implying catalytic selectivity to different inflammatory cytokines. ELISA kits further verified the immunoblot results that $\mathrm{Au}_{24} \mathrm{Cd}_{1}$ and $\mathrm{Au}_{24} \mathrm{Cu}_{1}$ are superior to $\mathrm{Au}_{25}$ on inhibiting inflammatory factors in brain tissues including IL-1 $\beta$, IL-6, and TNF- $\alpha$ (Fig. $7 d$, f). Additionally, the immuno histochemical assay illustrated the conspicuous anti-inflammation effect of $\mathrm{Au}_{24} \mathrm{Cd}_{1}$ and $\mathrm{Au}_{24} \mathrm{Cu}_{1}$ against IL-6 (Fig. $7 \mathrm{~h}$ ), consistent with quantitative results in Fig. 7 g. Furthermore, significant differences on the pathological slices can be seen that the TBI group exhibited swelling of nerve cells and obvious infiltration of inflammatory cells; while the groups treated with clusters especially the $\mathrm{Au}_{24} \mathrm{Cd}_{1}$ and $\mathrm{Au}_{24} \mathrm{Cu}_{1}$ recovered to almost normal (Fig. 7i). These results demonstrated that

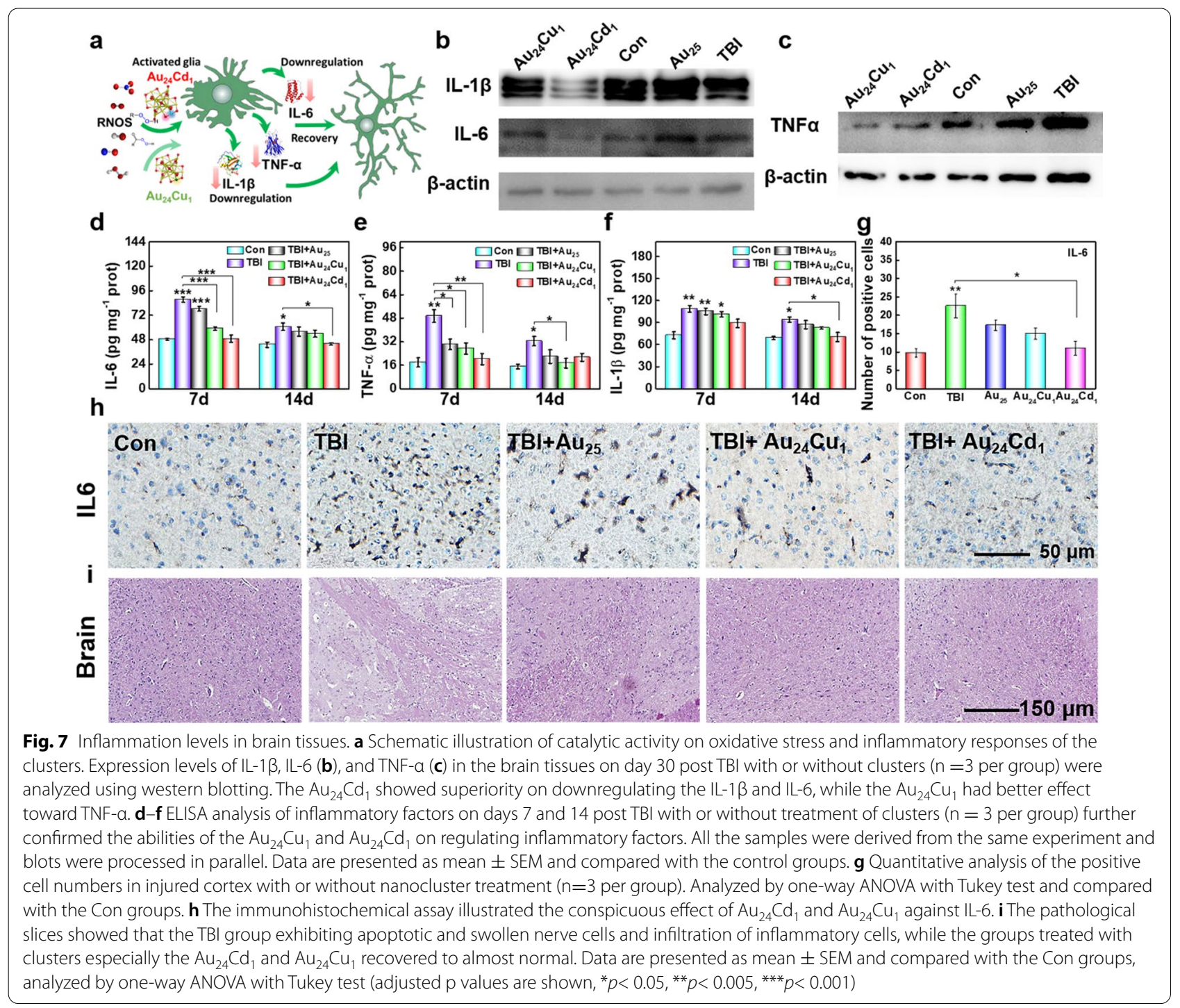


the clusters especially $\mathrm{Au}_{24} \mathrm{Cd}_{1}$ and $\mathrm{Au}_{24} \mathrm{Cu}_{1}$ can accelerate the wound healing of traumatically injured brain by inhibiting the inflammatory factors.

Brain injuries can also mediate the recruitment of microglia and astrocytes in the injuried areas, which are the key cellular mediators of TBI after brain injury [1]. As shown in Fig. 8a, lots of astrocytes are produced and activated along with inflammatory cytokines, indicating strong local inflammation. The $\mathrm{Au}_{24} \mathrm{Cd}_{1}$ and $\mathrm{Au}_{24} \mathrm{Cu}_{1}$ clusters can inhibit the activation of astrocytes and remarkably reduce the overexpression of IL- $1 \beta$ and IL- 6 . The relative quantification further exhibited the significant effect of $\mathrm{Au}_{24} \mathrm{Cd}_{1}$ and $\mathrm{Au}_{24} \mathrm{Cu}_{1}$ clusters (Fig. 8b-d). Immune response associated IL- $1 \beta$ and IL- 6 can be alleviated by $\mathrm{Au}_{24} \mathrm{Cd}_{1}$, while $\mathrm{Au}_{24} \mathrm{Cu}_{1}$ shows better effect on reducing TNF- $\alpha$, indicating their catalytic selectivity and potential selectivity towards the treatment of neuroinflammation. Also, it is noted that the performance of mice in $\mathrm{Au}_{24} \mathrm{Cu}_{1}$ and $\mathrm{Au}_{24} \mathrm{Cd}_{1}$ groups is superior to that in $\mathrm{Au}_{25}$ groups, indicating that $\mathrm{Au}_{24} \mathrm{Cu}_{1}$ and $\mathrm{Au}_{24} \mathrm{Cd}_{1}$ clusters possess a better anti-inflammation property by efficiently eliminating excessive free radicals and inhibiting neuroglia activation. Additionally, hematology analysis and tissue toxicology analysis showed no toxicity in the long term, suggesting the good biological safety of clusters (Additional file 1: Figs. S4-S6).

The present work demonstrated the high catalytic activity of $\mathrm{Au}_{24} \mathrm{Cd}_{1}$ and $\mathrm{Au}_{24} \mathrm{Cu}_{1}$ clusters and their availability as TBI therapeutics. Unlike traditional nanozymes, gold clusters overcomed the water insolubility and exhibited the well-defined structure at the atomic level with ultrasmall size and good biocompatibility. Catalytic activity and selectivity of clusters can be further increased and availability as TBI therapeutics can also be improved via single ation substitution. Moreover, since noninvasive administration can directly and rapidly release the biocatalysts into the damaged area, it shows promissing potential for TBI treatment, eliminating the RNOS and inhibiting subsequent neuroinflammation [15, 26, 56, 57]. Necessarily, exploiting new biocatalysts with high catalytic activities and favorable biocompatibility, and developing new delivery modes for the biocatalysts for the

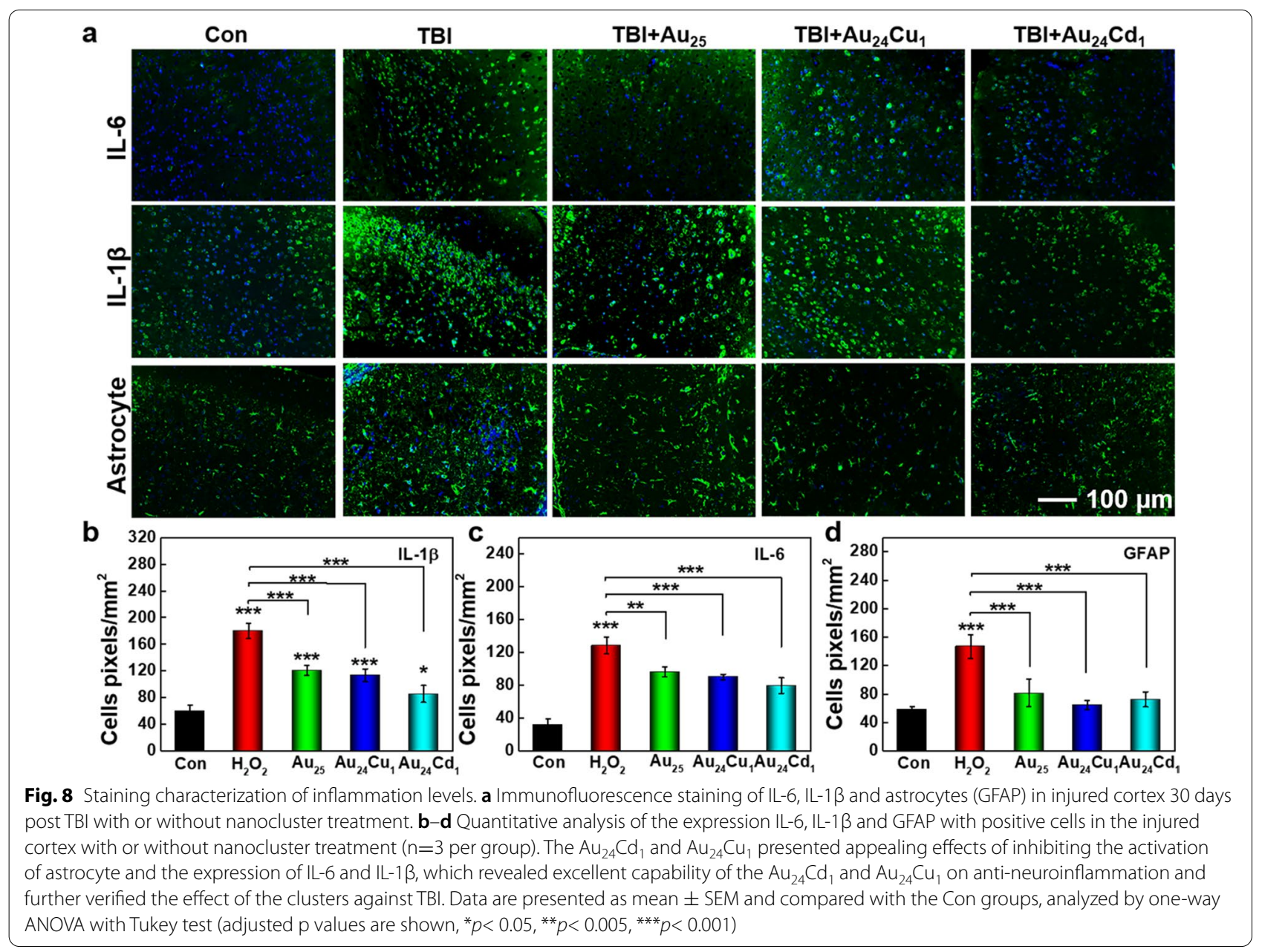


noninvasive intervention of TBI remain constant challenges in this field [15, 43]. As more biocatalysts with distinguished catalytic activities against oxidative stress are under development $[20,58]$, there will be more potential therapeutics in the use of noninvasive intervention against TBI.

\section{Conclusions}

In summary, we have reported a noninvasive therapeutic to treat brain trauma at the early stage with gold clusters of well-defined structure and high catalytic selectively. Compared with reported nanozymes, the gold clusters showed higher catalytic activities toward water splitting and reduction of $\mathrm{O}_{2}$ and $\mathrm{H}_{2} \mathrm{O}_{2}$ by introducing the $\mathrm{Cu}$ or $\mathrm{Cd}$ catalytic active site. The biological results reveal that clusters can modulate the oxidative stress and further alleviate neuroinflammation by noninvasive adminstration. Besides, these results conclude that $\mathrm{Au}_{24} \mathrm{Cd}_{1}$ preferentially decreases IL-1 $\beta$ and IL-6, while $\mathrm{Au}_{24} \mathrm{Cu}_{1}$ shows the tendency to decrease TNF- $\alpha$, indicating their different selectivity for alleviating neuroinflammation. Behaviors and histology illustrated their favorable effects against TBI after noninvasive administration. In conclusion, our work shows the great potential of noninvasive early intervention for the treatment of TBI with enzymatic biocatalysts.

\section{Materials and methods Materials and reagents}

All chemicals and reagents were purchased from commercial sources and used without further purification. Gold chloride $\left(\mathrm{HAuCl}_{4} \cdot 3 \mathrm{H}_{2} \mathrm{O}\right)$ was purchased from Sigma-Aldrich. Copper nitrate $\left(\mathrm{Cu}\left(\mathrm{NO}_{3}\right)_{2}\right)$, Cadmium nitrate $\left(\mathrm{Cd}\left(\mathrm{NO}_{3}\right)_{2}\right)$, 3-Mercaptopropionic acid (MPA), Sodium borohydride $\left(\mathrm{NaBH}_{4}\right)$, Sodium hydroxide $(\mathrm{NaOH})$, were purchased from Aladdin. Ultrapure water $\left(18.2 \mathrm{M} \Omega^{*} \mathrm{~cm}\right)$ was used for all the experiments. Kits and fluorescent probes were purchased from commercial sources and used as per the instructions.

\section{Materials preparation, characterization and catalytic activities}

The MPA-protected $\mathrm{Au}_{25}, \mathrm{Au}_{24} \mathrm{Cu}_{1}$ and $\mathrm{Au}_{24} \mathrm{Cd}_{1}$ clusters were prepared as per the previous reports $[26,59$, 60]. Briefly, $\mathrm{HAuCl}_{4}$ (aqueous, $20 \mathrm{mM}, 0.25 \mathrm{~mL}$ ) and MPA (aqueous, $5 \mathrm{mM}, 2 \mathrm{~mL}$ ) were added to water $(2.35$ $\mathrm{mL}$ ) and stirred for $5 \mathrm{~min}$ at room temperature. Then, $\mathrm{NaOH}$ solution (aqueous, $1 \mathrm{M}, 0.3 \mathrm{~mL}$ ) was added to the reaction mixture, followed by the addition of 0.1 $\mathrm{mL}$ of $\mathrm{NaBH}_{4}\left(43 \mathrm{mg}\right.$ of $\mathrm{NaBH}_{4}$ powder in $10 \mathrm{~mL}$ of $0.2 \mathrm{M} \mathrm{NaOH}$ solution). $\mathrm{Au}_{25} \mathrm{MPA}_{18}$ was collected after the final reaction mixture stirred at room temperature for $3 \mathrm{~h}$ in the dark and aged at $4{ }^{\circ} \mathrm{C}$ for $12 \mathrm{~h}$. The
$\mathrm{Au}_{24} \mathrm{Cu}_{1}$ and $\mathrm{Au}_{24} \mathrm{Cd}_{1}$ were synthesized based on the same method, except the Au atoms in $\mathrm{HAuCl}_{4}(20 \mathrm{mM}$, $0.25 \mathrm{~mL}$ ) were replaced by various nitrate metal ions $\left(\mathrm{Cu}^{2+}, \mathrm{Cd}^{2+}\right)$ at a $4 \%$ molar ratio. Ultrafiltration tubes of 3 and $10 \mathrm{~K}$ at $3500 \mathrm{rpm} / \mathrm{min}$ were used for ultrafiltration to remove smaller organic ligands and larger-sized clusters, and lyophilization was used to collect the purified product for further test and investigation.

A JEM-2100 F electron microscope (JEOL, Japan) was employed to acquire transmission electron microscopic (TEM) images. A Malvern Zetasizer Nano ZS90 (UK) was employed to measure dynamic light scattering (DLS) to test the hydrodynamic size and determine the zeta potential of clusters.

The XPS spectrum of the metal elements was performed using ESCALAB Xi+ spectrometer, with a monochromatic Al K $\alpha$ X-ray source (Thermo Fisher Scientific). All XPS spectra are processed with XPSPEAK41 software and corrected with the peak of C1s (standard: $428.8 \mathrm{eV}$ ). ICP-MS (Agilent, US) was used to determine the content of each metal element in the clusters.

The clusters were deposited onto the surface of glassy carbon (GC) electrodes for electrochemical assay [14, 40]. Briefly, as-prepared MPA-protected $\mathrm{Au}_{25}, \mathrm{Au}_{24} \mathrm{Cu}_{1}$ and $\mathrm{Au}_{24} \mathrm{Cd}_{1}$ clusters $(20 \mu \mathrm{L}, 0.5 \mathrm{mg} / \mathrm{mL})$ were deposited onto the surface of GC electrodes and dried naturally, then Nafion solution $(3 \mu \mathrm{L})$ was dropped onto the surface of GC electrodes and dried, the modified electrodes were used for catalytic activity tests.

Cyclic Voltammetry (CV, scan rate: HER, $10 \mathrm{mV} \mathrm{s}^{-1}$; OER, $100 \mathrm{mV} \mathrm{s}^{-1}$ ) and Linear Sweep Voltammetry (LSV, scan rate: HER, $1 \mathrm{mV} \mathrm{s}^{-1}$; OER, $5 \mathrm{mV} \mathrm{s}^{-1}$ ) measurements were taken electrochemical analyzer, CHI760E, Shanghai) to evaluate the performance of the clusters modified electrodes for HER and OER. HER was carried out in $0.5 \mathrm{M} \mathrm{H}_{2} \mathrm{SO}_{4}$, and a graphite rod and a saturated calomel electrode were used as the counter electrode and reference electrode, respectively. OER was carried out in $1 \mathrm{M}$ $\mathrm{KOH}$, and a platinum wire and an $\mathrm{Ag} / \mathrm{AgCl}$ electrode were used as the counter electrode and reference electrode, respectively.

$\mathrm{CV}$ (scan rate: $50 \mathrm{mV} \mathrm{s}^{-1}$ ) and LSV (scan rate: $5 \mathrm{mV}$ $\mathrm{s}^{-1}$ ) measurements were taken (electrochemical analyzer, CHI760E, Shanghai) to evaluate the catalytic activities for $\mathrm{O}_{2}$ and $\mathrm{H}_{2} \mathrm{O}_{2}$ reduction. A three-electrode cell was adopted for both $\mathrm{O}_{2}$ and $\mathrm{H}_{2} \mathrm{O}_{2}$ reduction, a platinum wire and a saturated calomel electrode were used as the counter electrode and reference electrode, respectively. Oxygen reduction reaction (ORR) was carried out in $\mathrm{O}_{2}$-saturated in $0.01 \mathrm{M} \mathrm{PBS}\left(\mathrm{pH}\right.$ 7.4), and the $\mathrm{H}_{2} \mathrm{O}_{2}$ reduction was performed in the presence of $9.8 \mathrm{mM}$ $\mathrm{H}_{2} \mathrm{O}_{2}$ in $\mathrm{N}_{2}$-saturated 0.01 M PBS (pH 7.4). 


\section{In vitro evaluation of the catalytic activities}

Cytotoxicity assay. mouse hippocampal neuronal cell line (HT22) $\left(3 \times 10^{3}\right)$, mouse microglia (BV2) $\left(4 \times 10^{3}\right)$, and mouse astrocytes $(\mathrm{MA}-\mathrm{c})\left(4 \times 10^{3}\right)$ were seeded in 96-well plates filled in $100 \mu \mathrm{L}$ medium with $0.01 \mathrm{M}$ PBS (Gibco) at the border overnight. The culture medium was replaced by different doses of $\mathrm{Au}_{25}, \mathrm{Au}_{24} \mathrm{Cu}_{1}$, or $\mathrm{Au}_{24} \mathrm{Cd}_{1}$ dissolved in the DMEM, and then cells were incubated for another $24 \mathrm{~h}$. Wells were washed with $0.01 \mathrm{M}$ PBS once, and the medium were replaced by fresh culture medium with serum-free DMEM. Cell survival was analyzed using MTT (3-(4,5-dimethyl2-thiazol)-2,5-diphenyl-2 $\mathrm{H}$ tetrazolium bromide, Beyotime) of $5 \mathrm{mg} / \mathrm{mL}$ for $2.5 \mathrm{~h}$ and detected at optical density (OD) $490 \mathrm{~nm}$.

Cell viability and Immunofluorescence. HT22 was used in all the cellular experiments. Cells were seeded into the 96-well plates and grew in Dulbecco's modified Eagle's medium (DMEM) at $37{ }^{\circ} \mathrm{C}$ with $5 \% \mathrm{CO}_{2}$. After being stimulated with $100 \mu \mathrm{M} \mathrm{H}_{2} \mathrm{O}_{2}$ for $6 \mathrm{~h}$, the culture medium was replaced by $\mathrm{Au}_{25}, \mathrm{Au}_{24} \mathrm{Cu}_{1}$ and $\mathrm{Au}_{24} \mathrm{Cd}_{1}$ dissolved in the DMEM at different doses, and then cells were incubated for another $24 \mathrm{~h}$. HT22 cells $\left(1 \times 10^{5}\right.$ cells per well) were seeded in 6-well plates for $12 \mathrm{~h}$ and stimulated with $100 \mu \mathrm{M} \mathrm{H}_{2} \mathrm{O}_{2}$ for $6 \mathrm{~h}$ before being treated with the clusters $(12 \mathrm{ng} / \mu \mathrm{L})$. Cell survival was determined at the MTT concentration of $5 \mathrm{mg} / \mathrm{mL}$ for $2.5 \mathrm{~h}$ and detected at optical density (OD) $490 \mathrm{~nm}$. Fluorescent staining was carried out to evaluate the intracellular oxidative stress levels with different probes such as DHE for $\mathrm{O}_{2}{ }^{--}$and DCFH-DA for ROS, and cell images were captured by a fluorescence microscope.

\section{In vivo treatment and behavioral experiment}

TBI models: C57BL/6 mice at 21-23 g were employed to establish TBI models using an electromagnetically CCI injury device (eCCI-6.3, Custom Design \& Fabrication, Inc), with an impactor of $5 \mathrm{~m} / \mathrm{s}$ velocity, $0.61 \mathrm{~mm}$ depth, $150 \mathrm{~ms}$ duration, and $20^{\circ}$ angle of dura mater on the vertical axis. The mice were divided into control, TBI, TBI+ $\mathrm{Au}_{25}, \mathrm{TBI}+\mathrm{Au}_{24} \mathrm{Cu}_{1}$, and TBI+ $\mathrm{Au}_{24} \mathrm{Cd}_{1}$ group $(\mathrm{n}=15)$ randomly. All mice were anesthetized with $10 \%$ chloral hydrate $(10 \mathrm{mg} / \mathrm{kg})$ and the scalp was cut before placed on the stereotaxic frame. The craniotomy was carried out by drilling the skull in a circle of 2 $\mathrm{mm}$ in diameter. The scalp was sewn together carefully, and the clusters were added to the wound of TBI mice at a concentration of $50 \mathrm{mg} / \mathrm{kg}$. The healing process was recorded photographically and the wound remaining was calculated after treatment.

Oxidative stress level: Brain tissues were taken out on days 7 and 14 post-treatment, then homogenized in $0.9 \%$ physiological saline and analyzed for SOD, GSH/GSSG,
MDA, and $\mathrm{H}_{2} \mathrm{O}_{2}$ using commercially available kits. All testing methods are carried out as per the instructions (Beyotime).

Morris water maze tests: Morris water maze (MWM) was conducted on days $13-17$ and $26-30$ post-treatment as described in the previously reported literature $[12,61$, 62]. Briefly, the water maze was divided into four quadrants, and the platform was set in the center of quadrant I. Before spatial learning, visual discrimination learning was performed to determine whether the vision of mice was normal. In this procedure, each animal performed one trial where the platform was placed above the water to determine whether the vision of mice was normal. Animal with the visual problem would be excluded in the Morris water maze test. Each mouse was put into the pool to be trained and learned to search for the platform under the water in the order of quadrant II, III, IV and I with an inter-trial interval (ITI) of $60 \mathrm{~min}$ at almost the same time of each day for five days. The test was carried out without the platform on the fifth day, and each mouse was put into the pool at quadrant II and allowed for $60 \mathrm{~s}$ to track them.

\section{Ex vivo verification}

Western Blotting: The total protein in the brain tissue was extracted and the content of IL- $1 \beta$ (1:1000), IL-6 (1:1000) and TNF- $\alpha$ (1:1000) was analyzed. SDS-PAGE electrophoresis was performed before transferring to the membrane. Immune responses of the specific antibodies were carried out and the images were captured with autoradiography. All antibodies were purchased from Abcam.

ELISA analysis: Inflammatory cytokines including IL-6, IL- $1 \beta$ and TNF- $\alpha$ were determined by ELISA kits (Abcam, ab100712, ab197742, ab208348, respectively), and the assays were performed as per the instructions provided by the manufacture.

Tissue staining: Brain tissues were taken out at 30 days post-injury and fixed in $4 \%$ paraformaldehyde and embedded in paraffin. Immunofluorescent staining was performed with primary antibodies including antiGFAP, IL-6, IL-1 $\beta$ antibodies as per the instructions of (Abcam). Then the slices were incubated with Alexa Fluor 488/594-conjugated goat secondary antibody for 1-1.5 $\mathrm{h}$ at room temperature under dark and counterstained with DAPI. Immunohistochemical staining for IL-6 and mice brain tissue was performed according to the instructions (Proteintech).

Toxicological studies: The biosafety of clusters was measured on male C57BL/6J mice at 7-8 weeks (21$23 \mathrm{~g})$. Mice were treated with $200 \mu \mathrm{L}$ of clusters at a dose of $50 \mathrm{mg} / \mathrm{kg}$ every other day. Hematology and blood biochemical indicators were tested on day 30 . 
The blood sample was obtained from the retroorbital sinus and stored in a test tube containing K2EDTA for testing. The blood sample used for biochemical analysis was allowed to stand for $30 \mathrm{~min}$, and then centrifuged twice at $3500 \mathrm{rpm}$ for $15 \mathrm{~min}$ each time, the supernatant was collected and tested. The main organs of the mice were collected and fixed in $4 \%$ paraformaldehyde for $24 \mathrm{~h}$, embedded in paraffin, and mounted on a glass slide $(4 \mu \mathrm{m}$ coronal section). The slices were stained with hematoxylin and eosin to observe the toxicity of clusters in major organs, including the heart, liver, spleen, lung, kidney and testis.

\section{Statistic methods}

Data are presented as mean \pm standard deviation (SD) or standard error of the mean (SEM). For multiple comparisons, one-way analysis of variance (ANOVA) was performed using the SPSS 22 software to assess difference in means among groups and compared with the Con and TBI groups, analyzed by ANOVA.

\begin{abstract}
Abbreviations
TBl: Traumatic brain injury; ROS: Reactive oxygen species; $\mathrm{OH} \cdot$ : Hydroxyl radical; $\mathrm{O}_{2}{ }^{-}$: Superoxide anion radicals; $\mathrm{H}_{2} \mathrm{O}_{2}$ : Hydrogen peroxide; RNS: Reactive nitrogen species; $\mathrm{NO}$ :: Nitric oxide radicals; $\mathrm{ONOO}^{-}$: Peroxynitrite; RONS: Reactive oxygen and nitrogen species; CAT: catalase; SOD: superoxide dismutase; POD: peroxidase; GPX: glutathione peroxidase; HER: hydrogen evolution reaction; OER: oxygen evolution reaction; DLS: dynamic light scattering; GC: glassy carbon; CV: Cyclic Voltammetry; LSV: Linear Sweep Voltammetry; ORR: Oxygen reduction reaction; ICP-MS: Inductively coupled plasma massspectrometry; XPS: X-ray photoelectron spectroscopy; ALT: Alanine aminotransferase; ALB: Albumin; AST: Aspartate aminotransferase; TP: Total protein; CREA: Creatinine; TB: Total bilirubin; BUN: Blood urea nitrogen; WBC: White blood cells; RBC: Red blood cell; HCT: Hematocrit; MCV: Mean corpuscular volume; HGB: Hemoglobin; PLT: Platelets; MCH: Mean corpuscular hemoglobin; MCHC: Mean corpuscular hemoglobin concentration.
\end{abstract}

\section{Supplementary Information}

The online version contains supplementary material available at https://doi. org/10.1186/s12951-021-01071-4.

Additional file 1: Figure S1. The content of metal elements in the clusters were quantified by ICP-MS. Figure S2. X-ray photoelectron spectroscopy of clusters. Figure S3. Cell survival of (a) HT22, (b) BV2 and (c) MA-c cells in the presence of various concentrations of clusters. Figure S4. Hematology of mice treated with or without gold clusters on day 30 . Figure S5. Blood biochemistry analysis of mice treated with or without gold clusters on day $\mathbf{3 0}$. Figure $\mathbf{5 6}$. Histology of major organs in mice.

\section{Acknowledgements}

Not applicable.

\section{Authors' contributions}

$Z X, W H$, and $X J$ originated the concept. ZY and SS wrote the manuscript. SS and $\mathrm{LH}$ worked on materials synthesis and characterizations. RQ, HW, and $\mathrm{XQ}$ worked on biological experiments. All authors read and approved the final manuscript.

\section{Funding}

This work was financially supported by the NSFC (Grant Nos. 91859101, 81971744, U1932107, and 81471786), the National Natural Science Foundation of Tianjin (19JCZDJC34000), the Foundation of 'Peiyang Young Researcher' Program of Tianjin University, and CAS Interdisciplinary Innovation Team (JCTD-2020-08).

\section{Availability of data and materials}

The datasets used and analyzed during the current study are available from the corresponding author on reasonable request.

\section{Declarations}

\section{Ethics approval and consent to participate}

We have obtained approval of animal ethics and use committee (IRMDWLL-2019099). All animal procedure was followed the guideline approved by the Institute of Radiation Medicine, Chinese Academy of Medical Sciences and Peking Union Medical College.

\section{Consent for publication}

All authors gave their consent for publication.

\section{Competing interests}

The authors declare no conflict of interest.

\section{Author details}

${ }^{1}$ School of Science, Xi'an University of Posts and Telecommunications, Xi'an 710121, China. ${ }^{2}$ Tianjin Key Laboratory of Low Dimensional Materials Physics and Preparing Technology, School of Sciences, Tianjin University, Tianjin 300350, China. ${ }^{3}$ Tianjin Key Laboratory of Brain Science and Neuroengineering, Academy of Medical Engineering and Translational Medicine, Tianjin University, Tianjin 300072, China.

Received: 15 June 2021 Accepted: 30 September 2021

Published online: 13 October 2021

\section{References}

1. Simon DW, McGeachy MJ, Bayır H, Clark RS, Loane DJ, Kochanek PM. The far-reaching scope of neuroinflammation after traumatic brain injury. Nat Rev Neurol. 2017:13(3):171-91.

2. Jiang JY, Gao GY, Feng JF, Mao Q, Chen LG, Yang XF, Liu JF, Wang YH, Qiu BH, Huang XJ. Traumatic brain injury in China. Lancet Neurol. 2019;18(3):286-95.

3. Zhang XD, Wang H, Antaris AL, Li L, Diao S, Ma R, Nguyen A, Hong G, Ma Z, Wang J, et al. Traumatic brain injury imaging in the second near-infrared window with a molecular fluorophore. Adv Mater. 2016;28(32):6872-9.

4. Badhiwala JH, Wilson JR, Fehlings MG. Global burden of traumatic brain and spinal cord injury. Lancet Neurol. 2019;18(1):24-5.

5. James SL, Theadom A, Ellenbogen RG, Bannick MS, Montjoy-Venning W, Lucchesi LR, Abbasi N, Abdulkader R, Abraha HN, Adsuar JC. Global, regional, and national burden of traumatic brain injury and spinal cord injury, 1990-2016: a systematic analysis for the Global Burden of Disease Study 2016. Lancet Neurol. 2019;18(1):56-87.

6. Kolias AG, Rubiano AM, Figaji A, Servadei F, Hutchinson PJ. Traumatic brain injury: global collaboration for a global challenge. Lancet Neurol. 2019;18(2):136-37.

7. Khatri N, Thakur M, Pareek V, Kumar S, Sharma S, Datusalia AK. Oxidative stress: major threat in traumatic brain injury. CNS Neurol Disord Drug Targets. 2018;17(9):689-95.

8. Lu Y, Zhang C, Li X, Frojd AR, Xing W, Clayborne AZ, Chen W. Significantly enhanced electrocatalytic activity of Au25 clusters by single platinum atom doping. Nano Energy. 2018;50:316-22.

9. Yang B, Chen Y, Shi J. Nanocatalytic medicine. Adv Mater. 2019;31(39):1901778.

10. Guo F, Zou Z, Zhang Z, Zeng T, Tan Y, Chen R, Wu W, Cheng N, Sun X Confined sub-nanometer PtCo clusters as a highly efficient and robust 
electrocatalyst for the hydrogen evolution reaction. J Mater Chem A. 2021;9(9):5468-74.

11. Geerts L, Cosentino S, Liao TW, Yadav A, Lin PC, Zharinov VS, Hu KJ, Longo A, Pereira LMC, Grandjean D, et al. Highly active oxygen evolution reaction model electrode based on supported gas-phase Nife clusters. Catal Today. 2019;334:59-67.

12. Zhang S, Liu Y, Sun S, Wang J, Li Q, Yan R, Gao Y, Liu H, Liu S, Hao W, et al. Catalytic patch with redox $\mathrm{Cr} / \mathrm{CeO}_{2}$ nanozyme of noninvasive intervention for brain trauma. Theranostics. 2021;11(6):2806-21.

13. Mu X, He H, Wang J, Long W, Li Q, Liu H, Gao Y, Ouyang L, Ren Q, Sun S, et al. Carbogenic nanozyme with ultrahigh reactive nitrogen species selectivity for traumatic brain injury. Nano Lett. 2019;19(7):4527-34.

14. Mu X, Wang J, Li Y, Xu F, Long W, Ouyang L, Liu H, Jing Y, Wang J, Dai H, et al. Redox trimetallic nanozyme with neutral environment preference for brain injury. ACS Nano. 2019;13(2):1870-84.

15. Yan R, Sun S, Yang J, Long W, Wang J, Mu X, Li Q, Hao W, Zhang S, Liu H, et al. Nanozyme-based bandage with single-atom catalysis for brain trauma. ACS Nano. 2019;13(10):11552-60.

16. Wang Q, Jiang J, Gao L. Nanozyme-based medicine for enzymatic therapy: progress and challenges. Biomed Mater. 2021;16:042002.

17. Smith ES, Porterfield JE, Kannan RM. Leveraging the interplay of nanotechnology and neuroscience: Designing new avenues for treating central nervous system disorders. Adv Drug Deliv Rev. 2019;148:181-203.

18. Tang ZH, Wu W, Wang K. Oxygen reduction reaction catalyzed by noble metal clusters. Catalysts. 2018;8:2.

19. Gu H, Yang Y, Tian JX, Shi GY. Photochemical synthesis of noble metal (Ag, $\mathrm{Pd}, \mathrm{Au}, \mathrm{Pt}$ ) on Graphene/ZnO multihybrid nanoarchitectures as electrocatalysis for $\mathrm{H}_{2} \mathrm{O}_{2}$ reduction. ACS Appl Mater Interfaces. 2013;5(14):6762-68.

20. Chen K, Sun S, Wang J, Zhang X-D. Catalytic nanozymes for central nervous system disease. Coord Chem Rev. 2021;432:213751.

21. Mendoza K, Derry PJ, Cherian LM, Garcia R, Nilewski L, Goodman JC, Mbye $L$, Robertson CS, Tour JM, Kent TA. Functional and structural improvement with a catalytic carbon nano-antioxidant in experimental traumatic brain injury complicated by hypotension and resuscitation. J Neurotrauma. 2019;36(13):2139-46.

22. Wang $X$, He H, Wang $Y$, Wang J, Sun $X, X u H$, Nau WM, Zhang $X$, Huang $F$. Active tumor-targeting luminescent gold clusters with efficient urinary excretion. Chem Commun. 2016;52(59):9232-5.

23. Tyo EC, Vajda S. Catalysis by clusters with precise numbers of atoms. Nat Nanotechnol. 2015;10(7):577-88

24. Hao W, Liu S, Liu H, Mu X, Chen K, Xin Q, Zhang X-D. In vivo neuroelectrophysiological monitoring of atomically precise $\mathrm{Au}_{25}$ clusters at an ultrahigh injected dose. ACS Omega. 2020;5(38):24537-45.

25. Zhang XD, Wu D, Shen X, Liu PX, Fan FY, Fan SJ. In vivo renal clearance, biodistribution, toxicity of gold nanoclusters. Biomaterials. 2012;33(18):4628-38.

26. Liu H, Li Y, Sun S, Xin Q, Liu S, Mu X, Yuan X, Chen K, Wang H, Varga K, et al. Catalytically potent and selective clusterzymes for modulation of neuroinflammation through single-atom substitutions. Nat Commun. 2021;12(1):1-14.

27. Xu J, Yu MX, Peng CQ, Carter P, Tian J, Ning XH, Zhou QH, Tu Q, Zhang G, Dao A, et al. Dose dependencies and biocompatibility of renal clearable gold nanoparticles: from mice to non-human primates. Angew Chem Int Edit. 2018;57(1):266-71.

28. Sun S, Liu HL, Xin Q, Chen K, Ma HZ, Liu SH, Mu XY, Hao WT, Liu SJ, Gao YL, et al. Atomic engineering of clusterzyme for relieving acute neuroinflammation through lattice expansion. Nano Lett. 2021;21(6):2562-71.

29. Yuan SF, Lei Z, Guan ZJ, Wang QM. Atomically precise preorganization of open metal stes on gold nanoclusters with high catalytic performance. Angew Chem Int Ed. 2021;60(10):5225-29.

30. Higaki T, Li Y, Zhao S, Li Q, Li S, Du XS, Yang S, Chai J, Jin R. Atomically tailored gold nanoclusters for catalytic application. Angew Chem Int Ed. 2019;58(25):8291-302.

31. Tian S, Cao Y, Chen T, Zang S, Xie J. Ligand-protected atomically precise gold nanoclusters as model catalysts for oxidation reactions. Chem Commun. 2020;56(8):1163-74.

32. Kudryashev JA, Waggoner LE, Leng HT, Mininni NH, Kwon EJ. An activitybased nanosensor for traumatic brain injury. ACS Sens. 2020;5(3):686-92.

33. Li C, Li W, Liu H, Zhang Y, Chen G, Li Z, Wang Q. An Aactivatable NIR-II nanoprobe for in vivo early real-time diagnosis of traumatic brain injury. Angew Chem Int Ed. 2020;59(1):247-52.
34. Li C, Shah KA, Narayan RK. Rapid detection of traumatic brain injury. Nat Biomed Eng. 2020;4(6):579-80.

35. Li Z, Ji S, Liu Y, Cao X, Tian S, Chen Y, Niu Z, Li Y. Well-defined materials for heterogeneous catalysis: from nanoparticles to isolated single-atom sites. Chem Rev. 2020;120(2):623-82.

36. Cai X, Saranya G, Shen KQ, Chen MY, Si R, Ding WP, Zhu Y. Reversible switching of catalytic activity by shuttling an atom into and out of gold nanoclusters. Angew Chem Int Ed. 2019;58(29):9964-68.

37. Kwak K, Lee D. Electrochemistry of atomically precise metal nanoclusters. Acc Chem Res. 2019;52(1):12-22.

38. Tang $Q$, Hu G, Fung $V$, Jiang DE. Insights into interfaces, stability, electronic properties, and catalytic activities of atomically precise metal nanoclusters from first principles. Acc Chem Res. 2018;51 (11):2793-802.

39. Xu BL, Wang H, Wang WW, Gao LZ, Li SS, Pan XT, Wang HY, Yang HL, Meng $\mathrm{XQ}, \mathrm{Wu} \mathrm{QW}$, et al. A single-atom nanozyme for wound disinfection applications. Angew Chem Int Ed. 2019;58(15):4911-16.

40. Zhang XD, Zhang J, Wang J, Yang J, Chen J, Shen X, Deng J, Deng D, Long W, Sun $Y M$, et al. Highly catalytic nanodots with renal clearance for radiation protection. ACS Nano. 2016;10(4):4511-9.

41. Chen D, Li J. Ultrasmall au nanoclusters for bioanalytical and biomedical applications: the undisclosed and neglected roles of ligands in determining the nanoclusters' catalytic activities. Nanoscale Horiz. 2020;5(10):1355-67.

42. Zhou R, Yan L, Dong X, Zhu S, Chen K, Wu Y, Xiang H, Li L, Zhang G, Gu $Z$, et al. Fractionated regimen-suitable immunoradiotherapy sensitizer based on ultrasmall $\mathrm{Fe}_{4} \mathrm{Se}_{2} \mathrm{~W}_{18}$ nanoclusters enable tumor-specific radiosensitization augment and antitumor immunity boost. Nano Today. 2021;36(3):101003.

43. Joseph B, Khan M, Rhee P. Non-invasive diagnosis and treatment strategies for traumatic brain injury: an update. J Neurosci Res. 2018;96(4):589-600.

44. Strubakos CD, Malik M, Wider JM, Lee IS, Reynolds CA, Mitsias P, Przyklenk K, Huttemann M, Sanderson TH. Non-invasive treatment with near-infrared light: A novel mechanisms-based strategy that evokes sustained reduction in brain injury after stroke. J Cerebr Blood F Met. 2020;40(4):833-44.

45. Pink AE, Williams $C$, Alderman $N$, Stoffels $M$. The use of repetitive transcranial magnetic stimulation (rTMS) following traumatic brain injury (TBI): a scoping review. Neuropsychol Rehabil. 2021;31(3):479-505.

46. Gao G, Chen R, He M, Li J, Li J, Wang L, Sun T. Gold nanoclusters for Parkinson's disease treatment. Biomaterials. 2019;194:36-46.

47. Liu H, Hong G, Luo Z, Chen J, Chang J, Gong M, He H, Yang J, Yuan X, $\mathrm{Li} \mathrm{L}$, et al. Atomic-precision gold clusters for NIR-II imaging. Adv Mater. 2019;31(46):1901015

48. Fan Y, Liu S, Yi Y, Rong H, Zhang J. Catalytic nanomaterials toward atomic levels for biomedical applications: from metal clusters to single-atom catalysts. ACS Nano. 2021;15(2):2005-37.

49. Zhu J, Cai L, Yin X, Wang Z, Zhang L, Ma H, Ke Y, Du Y, Xi S, Wee ATS, et al. Enhanced electrocatalytic hydrogen evolution activity in single-atom Pt-decorated VS 2 nanosheets. ACS Nano. 2020;14(5):5600-08.

50. Zhao S, Jin R, Abroshan H, Zeng C, Zhang H, House SD, Gottlieb E, Kim HJ, Yang JC, Jin R. Gold nanoclusters promote electrocatalytic water oxidation at the nanocluster/CoSe 2 interface. J Am Chem Soc. 2017;139(3):1077-80.

51. Wang JY, Mu X, Li Y, Xu F, Long W, Yang J, Bian P, Chen J, Ouyang L, Liu H, et al. Hollow PtPdRh nanocubes with enhanced catalytic activities for in vivo clearance of radiation-induced ROS via surface-mediated bond breaking. Small. 2018;14(13):e1703736

52. Seong H, Efremov V, Park G, Kim H, Yoo JS, Lee D. Atomically precise gold nanoclusters as model catalysts for identifying active sites for electroreduction of CO2. Angew Chem Int Ed. 2021;8:98.

53. Jiang Y, Zhao X, Huang J, Li J, Upputuri PK, Sun H, Han X, Pramanik M, Miao Y, Duan H, et al. Transformable hybrid semiconducting polymer nanozyme for second near-infrared photothermal ferrotherapy. Nat Commun. 2020;1 1(1):1857.

54. Fan $\mathrm{K}$, Xi J, Fan L, Wang $P$, Zhu C, Tang $Y$, Xu X, Liang M, Jiang B, Yan $X$, et al. In vivo guiding nitrogen-doped carbon nanozyme for tumor catalytic therapy. Nat Commun. 2018;9(1):1440.

55. Yong Y, Zhang C, Gu Z, Du J, Guo Z, Dong X, Xie J, Zhang G, Liu X, Zhao Y. Polyoxometalate-based radiosensitization platform for treating hypoxic 
tumors by attenuating radioresistance and enhancing radiation response. ACS Nano. 2017;11 (7):7164-76.

56. Ma M, Gao N, Li X, Liu Z, Pi Z, Du X, Ren J, Qu X. A biocompatible second near-infrared nanozyme for spatiotemporal and non-invasive attenuation of amyloid deposition through scalp and skull. ACS Nano. 2020;14(8):9894-903.

57. Wu H, Li F, Wang S, Lu J, Li J, Du Y, Sun X, Chen X, Gao J, Ling D. Ceria nanocrystals decorated mesoporous silica nanoparticle based ROSscavenging tissue adhesive for highly efficient regenerative wound healing. Biomaterials. 2018;151:66-77.

58. Liu Y, Cheng Y, Zhang H, Zhou M, Yu Y, Lin S, Jiang B, Zhao X, Miao L, Wei CW, et al. Integrated cascade nanozyme catalyzes in vivo ROS scavenging for anti-inflammatory therapy. Sci Adv. 2020;6(29):eabb2695.

59. Yuan X, Goswami N, Mathews I, Yu Y, Xie JP. Enhancing stability through ligand-shell engineering: $\mathrm{A}$ case study with $\mathrm{Au}_{25}(\mathrm{SR})_{18}$ nanoclusters. Nano Res. 2015:8(11):3488-95.
60. Yao Q, Chen T, Yuan X, Xie J. Toward total synthesis of thiolate-protected metal nanoclusters. Acc Chem Res. 2018;51(6):1338-48.

61. Vorhees CV, Williams MT. Morris water maze: procedures for assessing spatial and related forms of learning and memory. Nat Protoc. 2006;1(2):848-58.

62. D'Hooge R, De Deyn PP. Applications of the Morris water maze in the study of learning and memory. Brain Res Rev. 2001;36(1):60-90.

\section{Publisher's Note}

Springer Nature remains neutral with regard to jurisdictional claims in published maps and institutional affiliations.
Ready to submit your research? Choose BMC and benefit from:

- fast, convenient online submission

- thorough peer review by experienced researchers in your field

- rapid publication on acceptance

- support for research data, including large and complex data types

- gold Open Access which fosters wider collaboration and increased citations

- maximum visibility for your research: over 100M website views per year

At BMC, research is always in progress.

Learn more biomedcentral.com/submissions 